\title{
Plant species composition and diversity on the calcareous soils in around of the limestone quarry in Georgia, Caucasus region
}

\begin{abstract}
Preliminary study carried out in Georgia in the framework of limestone quarries in V. Kavtiskhevi, Municipality of Kaspi, Shida Kartli in coordinates $41^{\circ} 88^{\prime} \mathrm{N}-44^{\circ} 44^{\prime}$ E, elevation $386-709 \mathrm{~m}$. Post-closed rehabilitation process of the limestone quarry area after finishing the cement production is extremely interesting to use this territory for scientific investigations of industrial impact on nature and the methods of habitat rehabilitation. Plant species composition and diversity was determined for each habitat. Plant species are 114 total numbers in described on the territory $(182.98 \mathrm{~h})$ of the quarry. The endemics are 10 species: Shrubs (3); herbs (6), geophytes (1). The vegetation cover percentage is much lower in pioneer successions $(29.4 \pm 14.4)$ than in oligotrophic grasslands $(67.8 \pm 16.1)$. The species richness shows similarly low level at pioneer succession (9.7 \pm 1.6$)$ than in oligotrophic grasslands (16.4 \pm 3.9$)$. Shannon-Wiener index is higher in restored grasslands $(1.9 \pm 0.48)$ than in pioneer successions (1.6 \pm 0.53$)$. DCA show that the pioneer succession is mainly clustered with environmental indicator of low soil depth. The mean soil depth pioneer succession plots is lower $(1.7 \pm 1.76 \mathrm{~cm})$ than in oligotrophic grasslands $(2.75 \pm 1.13 \mathrm{~cm})$. The plant species presented in the second group of the dominant species are demonstrating the higher frequency: Poterium polygamum $(70.8 \%)$, Poa pratensis and Trisetum rigidum (66.7\%), Plantago lanceolata $(62.5 \%)$. the first dominant species Dorycnium pentaphyllum sub sp. herbaceum occurs only in $58.3 \%$ of the plots. The second dominant species Bothriochloa ischaemum occurs only in $37.5 \%$ of the plots. The frequency of other three species of the first dominant group-Lotus corniculatus, Glycyrrhiza glabra and Inula aspera equals to $20.8 \%$. Plant species are standard deviation, and minimum and maximum values were calculated for each quantitative data set one-way ANOVA. The area of Kavtiskhevi is semi-arid zone and the vegetation is adapted to dry matter of clay soil.
\end{abstract}

Volume 6 Issue 3 - 2018

\author{
Maia Akhalkatsi, Giorgi Arabuli, Natalia \\ Togonidze \\ Department of Plant Genetic Resources, Ilia State University, \\ Republic of Georgia
}

\begin{abstract}
Correspondence: Maia Akhalkatsi, Head of Department of Plant Genetic Resources, Faculty of Natural Sciences and Engineering, Institute of Botany, Ilia State University, K Cholokashvili 3/5, 0162 Tbilisi, Republic of Georgia, Email maia_akhalkatsi@iliauni.edu.ge
\end{abstract}

Received: March 06, 2018| Published: May 17, 2018

Keywords: calcareous soils, grasslands, limestone quarry, oligotrophic, plant species

\section{Introduction}

The information for educational working was collected from literature data and during field trips. The field work was carried out using phytosociological methods of plot recording. Plant species composition and diversity was determined for each habitat. Statistical analysis of these data gave a possibility to develop complete database information about species diversity changes among succession stages of vegetation recovery. The obtained data demonstrates the role of phytosociological investigation in determination of plant species used for re-vegetation process during post-closed rehabilitation of limestone quarry. ${ }^{1}$ Preliminary study carried out in summer 2012 in Georgia in the framework of the program "the Quarry Life Award" used for the education working two limestone quarries-Kavtiskhevi and Dedoplistskaro. ${ }^{1}$

Habitat disturbances effect on plant species density and fertility as indicator species has shown that the decrease of sky exposition due to wood cutting in quarry caused diminishing of species fertility index but increased of species density by vegetative propagation of nonflowering individuals. Habitat disturbances effect on plant species density and fertility as indicator species has shown that the decrease of sky exposition due to wood cutting in forest caused diminishing of species fertility index but increased of species density by vegetative propagation of non-flowering individuals. The fauna is represented by mammals: Canis lupus cubanensis, Vulpes vulpes, Canis aureus, Lepus europaeus; and birds: Merops apiaster, Aquila rapax orientalis, etc. as well as several kind of reptiles i.e. Viperidae, Natrix maura and insects. ${ }^{2}$ Negative linear correlation was determined between species density and sky exposition. ${ }^{3}$ More plant species individuals occurred in cutting forest with lower sky exposition and lower number was found in normal forest. Positive linear correlation was found between fertility and sky exposition. As higher is sky exposition as many species individuals are in flowering stage. This fact will negatively affect population because of diminishing the gene recombination and increase of clones of the species. This will increase threat to species extinction due to restricted genetic diversity in the population. Thus, during the possible restoration of area of limestone quarry geophytes of open meadows and shibliak will be restored from the early stages. ${ }^{1}$

The results of phytosociological investigations described natural re-vegetation process will provide important database for correct management and implementation of rehabilitation process. The information on species diversity changes during succession revegetation process will contribute in correct choice of plant species used in planting greenery process. This plant species might be considered as to highlight responsible limestone quarry rehabilitation activities from a range of local habitats around the world. To restore 
vegetation during post-closed quarry rehabilitation process needs knowledge on species diversity in this area to conduct restoration of natural habitats. ${ }^{3}$ However, the problem is that the extraction of raw materials for cement production from the earth's crust causes strong impacts on the surrounding natural environment. The biodiversity on active quarries is restricted and even restoration events will not rich the recovery of natural habitats because of changing the environmental conditions including soil quality and landscape topography. ${ }^{4}$ Therefore, for contribution in the habitat restoration process, it is necessary, to conduct investigations and determine pioneer plant species starting restoration process and conduct observation on new habitats to be created in the area. Environmental assessments for limestone landscapes have high value of unique biological, cultural, geological and scenic features. ${ }^{5}$ Therefore, this environmental area represents high interest for scientific investigations, environmental education and, as well, attracts large numbers of tourists. This process will be considered as involvement of stakeholders demonstrating a range of levels and activities, including information provision, consultation, participatory planning or decision-making and partnership. These activities will increase the popularity of rehabilitation process management and expand knowledge on nature conservation among young generation and local population. ${ }^{6}$

The educational working on biodiversity conservation will be prepared as an illustrated book on plant and animal species diversity in the limestone quarries of Heidelberg Cement AG in Georgia and online virtual interactive platform. The operation of this quarry was started in 1954 and is active till today managed by 'Heidelberg Cement AG' since May 2006, which interest contains restoration of habitats after implementation of quarry extraction. Limestone quarriesKavtiskhevi, will be used for the education working. The habitat types in the quarries are different. ${ }^{3}$ Kavtiskhevi limestone quarry is located in semi-arid zone of Kartli region in Georgia and natural habitats are xerophytic scrubland and secondary steppes. ${ }^{7}$ Limestone mining in Kavtiskhevi quarry was started since 1936 years demonstrating natural habitat restoration process, already representing by different succession stages of vegetation cover and containing restoration area of planted natural trees. ${ }^{8}$

The aims of this results will be the following tasks: 1) to maintain and enhance landscape quality and character in the limestone quarries in Kavtiskhevi; 2) to protect the historic environment and natural resources of quarries; 3 ) to promote public access and understanding of the importance of habitat rehabilitation process; 4) to offer access of pupils and students to education working on habitat natural restoration; 5) to popularize nature conservation process and maintain of habitat quality.

\section{Methodology}

\section{Study area}

The work was done on the limestone quarries during the field expiration. The characterization of the quarries should include: the geomorphologic features found in limestone deposits; history of the origin of the limestone deposits and fossils; biodiversity descriptions of limestone habitats; anthropogenic impact assessment. Total area of the quarry is 182.98 hectares, $80 \%$ is opened. We studied plant diversity in Kavtiskhevi quarry and numbers are as lower N41.88644/ E44.44503 and as higher N41.88770/E44.44733. Abbreviations of meters above sea level are elevation as lower $386 \mathrm{~m}$ a.s.l. and as higher $709 \mathrm{~m}$ a.s.l. (Figure 1). The climate is dry moderate continental average annual temperature is $+11.5^{\circ} \mathrm{C}$, average annual precipitation is $500 \mathrm{~mm}$. This area was investigated during the Quarry Life Award program in 2012. The field work was carried out using methods of plot recording. For this purpose twelve $1 \mathrm{~m}$ plots were chosen within each succession stages of re-vegetation process-pioneer and logistic successions. These cinnamon calcareous soils are characterized by alkaline or strongly alkaline $(\mathrm{pH} 6.65-9.3)$ and it is low or high carbonated (7.54-37.34\%). Natural areas with cinnamon soil contains more humus (1.33-3.5\%) and arable and ruderal habitats the low content of humus $(0.95-2.21 \%)$ showing that the area has been eroded.

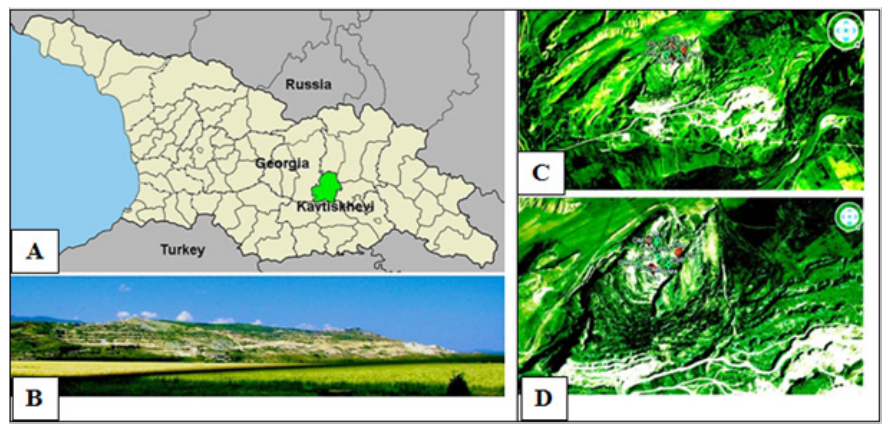

Figure I (A) Kavtiskhevi limestone quarry located is in Shida Kartli region of Georgia. (B) Kavtiskhevi limestone quarry. (C) Limestone quarry with study sites (red and green spots). (D) Research plots of pioneer successions (PS) and oligotrophic grasslands (OM) successions.

\section{Study site measures}

These activities were undertaken in the following schedule: 1 . March-April: Collection of plant species data and preparation of field plans and missions. 2. May-July: 201 field trips in Kavtiskhevi regions to assess plant communities of different succession stages. 3 . August-September: data analyses and preparation for environmental educational working on biodiversity conservation. The investigation was carried out using methods of plot recording. Preference is given to the square shape of the recording plots. For this purpose 25 plots of size $1.2 \mathrm{~m}^{2}$ will be chosen within each habitat types covered by populations of plant species. The time of inventory will be coincided to two phenological phases in each population at flowering and fruiting stages. For each plot, photos will be taken from fixed points during each visit.

The following parameters will be determined on the base of data collected during field observations: 1 . Data for documentation of the record: plot No., location, figure (s), map and date of field material collection, exact GPS coordinates; 2. Environmental data: Species composition of succession stages; altitude and sloping characters of plant species distribution: exposition, inclination $\left({ }^{\circ}\right)$, Elevation $(\mathrm{m}$ a.s.1.); 3. Plant community characteristics per habitat types: Vegetation cover (\%) and canopy height (cm;m); Plant community characteristics $\left(1 \mathrm{~m}^{2}\right.$ plots): Species richness and cover $(\%)$; height of habitat vertical structure $(\mathrm{m})$; species number of life forms: trees, shrubs, grasses, herbs, sedges, parasites, vines, ferns. 4). Species diversity determined as total number of individuals of plant species as indicator species in all studied $1 \mathrm{~m}^{2}$ plots; 5). Overall ecological state is of vitality and fertility of indicator plant species; 6). Main threats impacted the habitat types and indicator species.

We have calculated this value using fish-eye lens attached on digital camera Nikon Cool Pix 5500. The photos of area $180^{\circ} \mathrm{C}$ have 
been taken above research plots. The data showed percentage of open area in the $180^{\circ} \mathrm{C}$ ambient. The equation we use is: $\mathrm{D}=\mathrm{n} / \mathrm{A}$. (' $\mathrm{n}$ ' is number of individuals of all plant species in one unit area; 'A' is plot size $1 \mathrm{~m}^{2}$ ). Second measurement was done for species fertility in the same 20 plots have been accounted at each research sites. Fertility was determined as number of flowering individuals of plant species in the same plot where species density is calculated. ${ }^{9}$

\section{Data analyses}

To compare environmental data of habitat types, vegetation cover and canopy height is used one-way ANOVA $(p<0.05)$. We tested for spatial autocorrelation in two habitat types of primary and degraded vegetation (sky exposition and species density and fertility) using the software package SPSS v. 16. The calculation of sky exposition was done using digital images were imported into Gap Light Analyser software (Version 2.0, Simon Fraser University, Burnaby, British Columbia, Canada, and Institute of Ecosystem Studies, Millbrook, New York, U.S.A.) and used to calculate the fraction of the hemispherical image not obscured by objects (i.e. percent sky exposition). Discriminant function analysis (DFA) is used to determine the relation among studied habitat types environmental data and species composition. We performed a Detrended Correspondence Analysis (DCA) to demonstrate relationships between species distribution and environmental conditions among plots of habitat types. Environmental data: habitat types, inclination, elevation, vegetation cover, height of trees, secondary trees, shrubs and herbs, sky exposition, species density and fertility and summary data of species composition were determined as important 16 characters for the differences in habitat types during conducting a principal components analysis (DFA) based on correlation matrix. The analyses were performed using Statistics 16.0, PC-ORD 5.33 and Statistica 6.0.

\section{Results}

The quarry is located in semi-arid zone of Kartli region of Georgia, $5 \mathrm{~km}$ southeast of the town Kaspi, districts centre. The geologically limestone ground material is represented by small hills near R. Mtkvari right bank (Figure 1). The degraded habitat of limestone quarry in the Kavtiskhevi is covered by few plant species of semi-arid vegetation. Plant species are 114 total numbers in described on the territory (182.98h) of the quarry (Figure 2). The 7 species have revealed higher observed indicator value (IV) in pioneer successions. The following species are present only in pioneer successional plots-Chenopodium album (Amaranthaceae), Sisymbrium loeselii (Brassicaceae), Medicago lupulina (Fabaceae), Lactuca seriola (Compositae), Tussilago farfara (Compositae), Scorzonera biebersteinii (Compositae), Poa densa (Poaceae). The three dominant species of pioneer successions-Lotus corniculatus (Fabaceae), Melilotus officinalis (Fabaceae) and Taraxacum campylodes (Composite) showing high cover percentage in plots of pioneer successions are still remained in a logistical successional stage on plots. These species mainly cover the mining sites where limestone material was extracted 2-3 years ago. Most of these species are not present in other habitats of quarry covered by restored vegetation types and have to be determined as a pioneer species. The pioneer species should be determined for rehabilitation process of quarries and be used in re-vegetation process by sawing the seeds. The scrublands and steppe vegetation contains some endemic and rare species which are under threat and only few locations of them are discovered in Georgia. The endemics are 10 species. Shrubs are endemics 3 species:
Cotoneaster saxatilis Pojark. (Rosaceae); Daphne axilliflora (Keissl.) Pobed. (Thymelaeaceae); Daphne caucasica Pall. (Thymelaeaceae). Endemic herbs are 6 species: Amberboa moschata (L.) DC. (Compositae); Jurinea blanda (M. Bieb.) C. A. Mey. (Compositae); Onobrychis iberica Grossh. (Fabaceae); Onobrychis radiata (Desf.) M. Bieb. (Fabaceae); Scorzonera biebersteinii Lipsch. (Compositae); Thymus tiflisiensis Klok. \& Des.-Shost. (Lamiaceae). Geophyte is one endemic species: Gagea chanae Grossh. var. Chanae (Liliaceae). Plant species number and habitat types are standard deviation, and minimum and maximum values were calculated for each quantitative data set one-way ANOVA (Table 1).

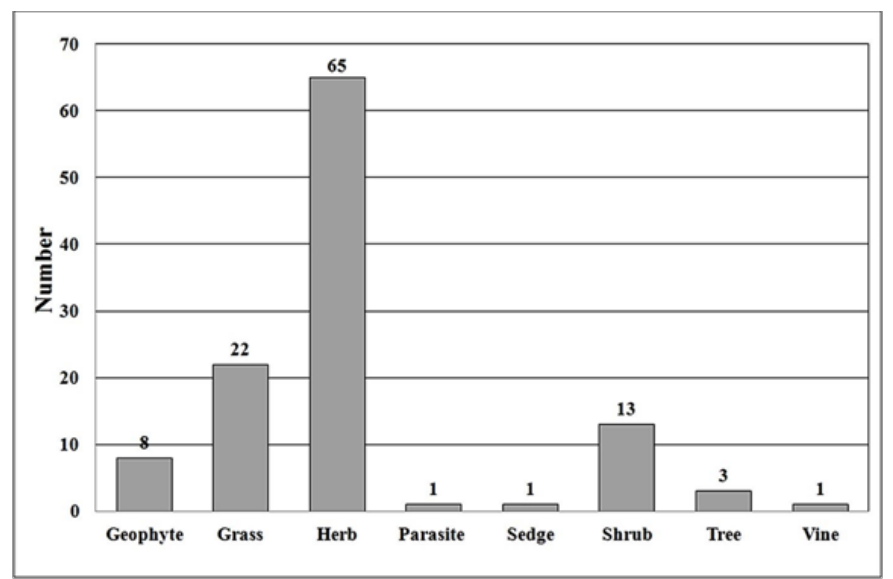

Figure 2 Plant diversity is in Kavtiskhevi limestone quarry. Number of plant species of different life forms in four habitats of the study area $(\mathrm{N}=|| 4)$.

Table I The results of one-way analysis of variance (ANOVA) for the plant species are able to grow on very open limestone ground material with low depth of clay soil and with reduced trophicity of the soil. Plants are in II4 species and some are as low trees, shrubs, grass and herbs. $(\mathrm{N}=12$; $\mathrm{Sig}$. < $0.0001)$.

\begin{tabular}{llll}
\hline Characteristic & Mean Square & F & Significance \\
\hline Exposition & 1426.042 & 0.612 & $0.000 \mathrm{I}$ \\
Soil depth & 8.167 & 3.379 & $0.000 \mathrm{I}$ \\
Max cover & 2109.375 & $18.04 \mathrm{I}$ & $0.000 \mathrm{I}$ \\
Light soil & 5.042 & 1.028 & $0.000 \mathrm{I}$ \\
Light plant & 24 & 1.437 & $0.000 \mathrm{I}$ \\
Low tree & 33525.38 & 1.562 & $0.000 \mathrm{I}$ \\
Up shrub & 416.667 & 0.043 & $0.000 \mathrm{I}$ \\
Low shrub & 2016.667 & $0.94 \mathrm{I}$ & $0.000 \mathrm{I}$ \\
Low grass & $18 \mathrm{I} .5$ & 0.315 & $0.000 \mathrm{I}$ \\
Low herb & 0.375 & $0.00 \mathrm{I}$ & $0.000 \mathrm{I}$ \\
Low geophyte & 145.042 & 2.362 & $0.000 \mathrm{I}$ \\
Low parasite & 247.042 & 23.846 & $0.000 \mathrm{I}$ \\
\hline
\end{tabular}

Number of vascular plant species of different life forms in pioneer primary successional (PS); logistic succession oligotrophic meadows $(\mathrm{OM})$; secondary steppes (St) and dry xerophyte scrubland $(\mathrm{Sc})$ are in study habitat types (Figure 3). Two successional stages: pioneer succession and typical oligotrophic meadows of Kavtiskhevi quarry have been described (Figure 4). The vegetation cover percentage is much lower in pioneer successions $(29.4 \pm 14.4)$ than in oligotrophic 
grasslands $(67.8 \pm 16.1)$. The species richness shows similarly low level at pioneer succession $(9.7 \pm 1.6)$ and higher value at the restored oligotrophic grasslands (16.4 \pm 3.9$)$. However, evenness is not significantly different between pioneer successions $(0.7 \pm 0.2)$ and restored oligotrophic grasslands $(0.69 \pm-0.15)$. Shannon-Wiener index is higher in restored grasslands $(1.9 \pm 0.48)$ than in pioneer successions $(1.6 \pm 0.53)$. The species richness is many numbers; elevation and Shannon-Wiener index have problems in these areas (Figure 5A). Dominance-diversity curves show the abundance distribution among species in plots of the pioneer successions and oligotrophic grasslands (Figure 5B). The scatterplot of the relationships between frequency and abundance of the plant species (log base 10 of the sum of the species cover) in the succession plots at the Kavtiskhevi quarry demonstrates the species which are very frequent in the area regardless of the fact that they have lower abundance and are distinguished from the dominant species presented in only a few instances but with high cover.

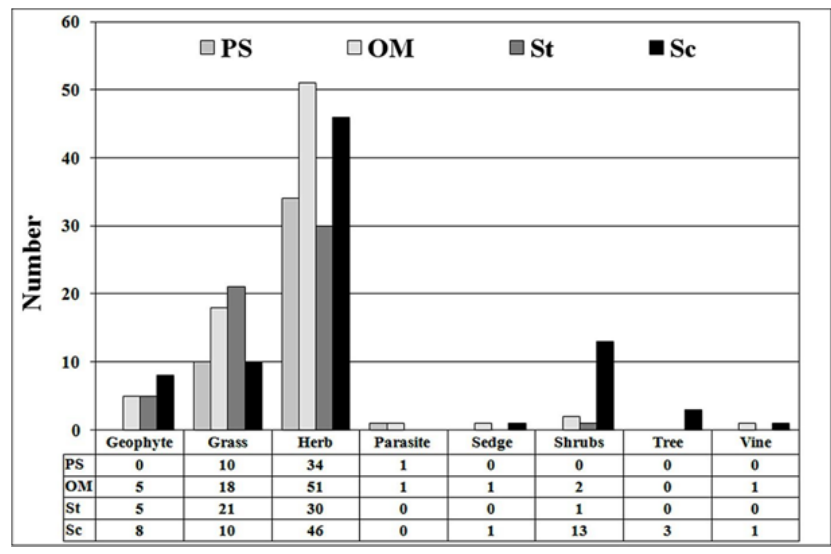

Figure 3 The number of life forms of vascular plant species in study habitat types: pioneer primary succession (PS); logistic succession oligotrophic meadows (OM); secondary steppes (St) and dry xerophytic scrubland (Sc). $(\mathrm{N}=|| 4)$.

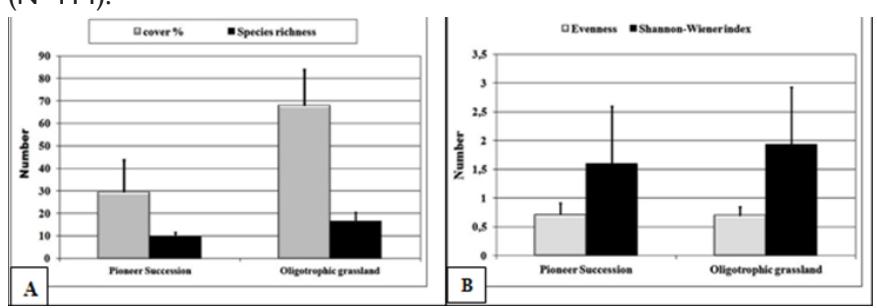

Figure 4 (A) Plant species cover percentage and species richness at the pioneer successions and naturally restored oligotrophic grasslands. $(n=67)$. (B) Evenness and Shannon-Wiener diversity index at pioneer successions and naturally restored oligotrophic grasslands. $(n=67)$.

Detrended correspondence analyses (DCA) show that the pioneer succession are mainly clustered in right segment of first axis area with environmental indicator of low soil depth and the oligotrophic grassland plots are concentrated in the area with more higher soil depth and litter occurrence. There are only four plots of pioneer succession with higher soil depth and they are clustered in left segment of the first axis. One oligotrophic plot (OM6) is associated with lower soil depth. The mean soil depth (Figure 5C) in pioneer succession plots is lower $(1.7 \pm 1.76 \mathrm{~cm})$ than in oligotrophic grasslands $(2.75 \pm 1.13 \mathrm{~cm})$.

The dendrogram (Figure 5D) shows the resulting hierarchy of clusters composed by two successional stages of naturally restoring vegetation at the limestone quarry. The first cluster group contains all plots of pioneer succession-PS12 to show high similarity and only one logistic successional plot of oligotrophic grassland-OM5 shows lower similarity to the pioneer successions. This is the only one logistical plot containing pioneer species-Taraxacum campylodes, which occurs in almost all pioneer successional plots but not in any other logistical plots. One oligotrophic grassland plot (OM6) is completely separated to other logistical plots. This plot contains as well the pioneer species-Lotus corniculatus, occurring only in plots of pioneer succession. The plot OM11 contains pioneer speciesMelilotus officinalis and is separated by low level of similarity to cluster of oligotrophic grasslands.

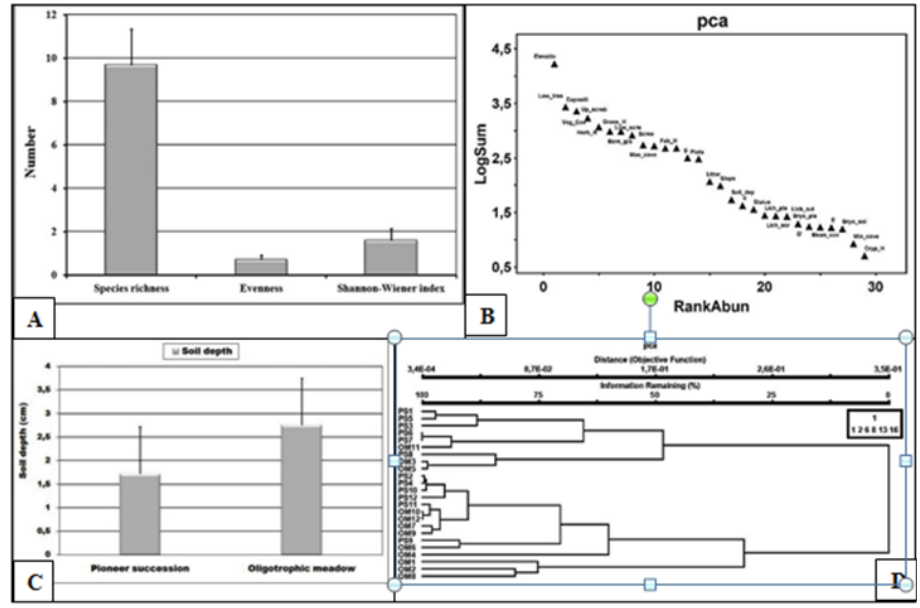

Figure 5 (A) Species richness, evenness and Shannon-Wiener index at the Pioneer successions of the Kavtiskhevi limestone quarry. $(N=12)$. (B) Dominant species in Kavtiskhevi quarry plant communities. $(n=67)$. (C) Detrended Correspondence Analysis (DCA) analyses of pioneer succession plots (red triangular) and oligotrophic grasslands (green triangular; $n=24 / 67$ ). (D) Cluster analyses of pioneer successions (PS) and oligotrophic grasslands (OM) $(n=24)$.

The plant species presented in the second group of the dominant species are demonstrating the higher frequency: Poterium polygamum (70.8\%), Poa pratensis and Trisetum rigidum (66.7\%), Plantago lanceolata (62.5\%). the first dominant species Dorycnium pentaphyllum subsp. herbaceum occurs only in $58.3 \%$ of the plots. The second dominant species Bothriochloa ischaemum occurs only in $37.5 \%$ of the plots. The frequency of other three species of the first dominant group-Lotus corniculatus, Glycyrrhiza glabra and Inula aspera equals to $20.8 \%$.

\section{Discussion}

The method combines the information on the concentration of species abundance and a faithfulness of occurrence of a species in a particular group. ${ }^{10}$ Perfect indication means that presence of a species points to a particular group without error. ${ }^{11}$ The significance of observed maximum indicator value for species was done by Monte Carlo test. The cluster results demonstrate importance of species composition for determining of successional stages. The following species are present only in pioneer successional plots-Chenopodium album, Lactuca serriola, Medicago lupulina, Poa densa, Scorzonera biebersteinii, Sisymbrium loeselii, Tussilago farfara. The three dominant species of pioneer successions-Lotus corniculatus, Melilotus officinalis and 
Taraxacum campylodes showing high cover percentage in plots of pioneer successions are still remained in a logistical successional stage on plots. Thus, to think about post-closed rehabilitation of the quarry area after finishing the cement production is extremely interesting to use this territory for scientific investigations to demonstrate effect of industrial impact on nature and the methods of habitat rehabilitation ${ }^{3}$ The oligotrophic grasslands with low level of dry matter have demonstrated high number of indicator species occurring in almost all plots-Bothriochloa ischaemum, Brachypodium distachyon, Dactylis glomerata, Dorycnium pentaphyllum subsp. herbaceum, Euphorbia falcata, Festuca varia, Inula aspera, Linum tenuifolium, Onobrychis radiata, Plantago lanceolata, Poa pratensis, Poterium polygamum, Teucrium chamaedrys, Teucrium polium, Thymus tiflisiensis, Tragopogon pusillus, Trisetum rigidum. These species are characterized for natural habitats of semi-arid zone of this area; however, the species combination is different than in natural habitats of semi-deserts, steppes, xerophytic scrublands etc.

The results show relationship of species composition in different successional stages with soil depth and structure. ${ }^{12}$ The pioneer species are able to grow on very open limestone ground material with low depth of clay soil and with reduced tornadoes of soil. Naturally restored grasslands remained oligotrophic, because the soil depth is low, but there is already litter and no complete open ground material areas. The restoration of pioneer succession to logistic succession stage will be connected to improvement of soil quality. The area of Kavtiskhevi is semi-arid zone and the vegetation is adapted to dry matter of clay soil. ${ }^{7}$ In spite of this fact, the oligotrophic grasslands with low level of dry matter have demonstrated high number of indicator species occurring in almost all plots.

We have compared vegetation cover, species richness and biodiversity indexes between pioneer successions located at the mineral extraction sites before $2-3$ years and restored oligotrophic grasslands covering areas of the mineral extraction sites after 5 years of naturally restoration process of the vegetation in the Kavtiskhevi limestone quarry of 'Heidelberg Cement AG'. Both pioneer successions and oligotrophic grasslands are characterized by low dry matter yields which can be explained through the reduced quantities of rainfall from spring and, of course, through with the reduced tornadoes of soil. Dominant species of the naturally restored grasslands in the Kavtiskhevi limestone quarry was used for determination of the abundance distribution among species in plots of the pioneer successions and naturally restored oligotrophic grasslands. ${ }^{7}$ Species abundance patterns in different tropical successional stages provide the niche in groups of species that are closely associated ecologically in the same microhabitats. The first group of dominant species is-Artemisia alpina, Bothriochloa ischaemum, Dorycnium pentaphyllum subsp. herbaceum, Glycyrrhiza glabra, Inula aspera, Lotus corniculatus. The second group contains species-Festuca varia, Lolium rigidum, Onobrychis radiata, Plantago lanceolata, Poa pratensis, Poterium polygamum, Teucrium chamaedrys, Trisetum rigidum, etc.

These data indicate that the pioneer species and dominants of logistic successional plots should be used for re-vegetation process. A very common goal in plant community analysis is to detect and describe the value of different species for indicating the environmental conditions. This type of investigations will contribute in rehabilitation process of the limestone quarry.
The vegetation of calcareous soil and limestone ground material habitats are characterized by high diversity and highest level of endemism. ${ }^{3}$ The study area is based on limestone ground material and plants are adapted to these concrete conditions. Therefore, there are many species typical for calcareous soils and limestone areas. After mining process of the quarry structure and conditions is changed and the restoration process should be determined depending on current structure and quality of environmental conditions of the quarry.

Thus, the educational working that contains study of species diversity and natural successional re-vegetation process will contribute to rehabilitation process. The monitoring of the rehabilitation process will be used for educational working to provide knowledge of young generation on effective protection of nature.

\section{Conclusion}

The natural habitat types in the quarry area are represented by xerophytes scrublands and secondary steppe grasslands. Xerophytes scrublands are almost completely degraded. However, the remnants of species are remained on small grounds, mainly in stony slopes. Secondary steppes are in the surrounding area. The degraded grassland area is presented by pioneer successions of plant pioneer species and logistic successions identified as oligotrophic meadows and mesotrophic meadows. The secondary steppes occupy areas at the limestone quarry which was operated since 1936 and the habitats have been restored naturally as grasslands of the dry climate which is characteristic of this region. The typical species composition for the secondary steppes of the Kartli semi-arid region is more or less restored in this area; however the territories are just small.

\section{Acknowledgements}

Support was provided by 'Heidelberg Cement AG' program "The Quarry Life Awards" where our project "Environmental Education Program for Biodiversity Conservation during the Rehabilitation Process of Limestone Quarry" was awarded by National contest Georgia- $1^{\text {st }}$ prize in 2012 .

\section{Conflict of interest}

The author declares that there is none of the conflicts.

\section{References}

1. Akhalkatsi M, Arabuli G, Lorenz R. Orchids as indicator species of forest disturbances on limestone quarry in Georgia (South Caucasus). Journal Europäischer Orchideen. 2014;46(1):123-160.

2. Tarkhnishvili D, Gavashelishvili A, Mumladze L. Palaeoclimatic models help to understand current distribution of Caucasian forest species. Biol J Linn Soc. 2012;105(1):231-248.

3. Akhalkatsi M, Tarkhnishvili D. Habitats of Georgia. Georgia; 2012.

4. Akhalkatsi M. Forest Habitat Restoration in Georgia, Caucasus Ecoregion. Georgia; 2015. p.1-115.

5. Nakhustrishvili G. The Vegetation of Georgia (South Caucasus). Germany: Berlin, Springer-Verlag; 2013.

6. Akhalkatsi M, Gvaladze G, Girgvliani T. Situational Analyses of the Current State of Plant Genetic Resources Important for Food and Agriculture in Georgia (Caucasus Ecoregion). ARTOAJ. 2016;2(2):1-5. 
7. Kimeridze M. Vascular Plants of Xerophylous Phytolandscapes of Shida Kartli Region (Central Part of Eastern Georgia). Georgia; 2009.

8. Maruashvili M. Physical geography of Georgia. Georgia: Metsniereba; 1964.

9. Akhalkatsi M, Pfauth M, Calvin C. Structural aspects of seed and ovule development and non-random abortion in Melilotus officinalis (Fabaceae). Protoplasma. 1999;208(1-4):211-223.

10. Korakhashvili A, Kirvalidze D, Kvrivishvili T, et al. Cinnamon Calcareous Soil Fertilizing Systems for Pastures of Akhaltsikhe District. Bulletin of the Georgian National Academy of Sciences. 2009;3(3):176-184.
11. Dufrene M, Legendre P. Species Assemblages and Indicator Species: The Need for a Flexible Asymmetrical Approach. Ecological Monographs. 1997;67(3):345-366.

12. Togonidze N, Akhalkatsi M. Variability of plant species diversity during the natural restoration of the subalpine birch forest in the Central Great Caucasus. Turkish Journal of Botany. 2015;39:458-471. 